\title{
PENERAPAN METODE FUZZY TSUKAMOTO DALAM MEMBANTU PERENCANAAN PERSEDIAAN BAHAN BAKU KAYU PADA INDUSTRI FURNITUR
}

\author{
Dian Eko Hari Purnomo', Yogi Akbar Sunardiansyah ${ }^{2}$, Amelia Nur Fariza ${ }^{3}$ \\ ${ }^{1,2}$ Program Studi Manajemen Bisnis Industri Furnitur,Politeknik Industri Furnitur dan Pengolahan Kayu \\ Jln. Wanamarta Raya No. 20, Kawasan Industri Kendal (KIK), Wonorejo, Kaliwungu, Kendal \\ ${ }^{3}$ Jurusan Teknik Industri, Fakultas Teknik dan Ilmu Komputer, Universitas Buana Perjuangan Karawang \\ Jln. HS. Ronggowaluyo, Telukjambe Timur, Karawang \\ E-mail: dian.eko.hari.p@gmail.com
}

\begin{abstract}
The furniture industry is experiencing the problem of uncertainty in determining the optimal amount of wood raw material inventory. Fuzzy logic is one of the methods used to analyze systems that contain uncertainty. This study discusses the application of fuzzy logic in solving the problem of supplying wood raw materials in the furniture industry with the Fuzzy-Mamdani approach. The data used in this study are data on the entry, distribution, and supply of wood raw materials from January to December 2018. The design of the system to obtain output is carried out in the following stages: (a) Formation of fuzzy sets, (b) Application of functions implications, (c) Composition of rules, (d) Affirmation (defuzzification). Solving the problem using the Fuzzy Tsukamoto method is carried out by the Tsukamoto method with the help of Visual Basic software so that the desired results will be obtained on the output variable. From the results of calculations using the Fuzzy Tsukamoto method, it can be analyzed that the comparison between the realized wood raw material inventory with the Fuzzy Tsukamoto approach looks different and the results from the Fuzzy Tsukamoto approach are more optimal.
\end{abstract}

Keywords: uncertainty; supply of wood raw materials; Fuzzy logic; Tsukamoto method

\begin{abstract}
ABSTRAK
Pada industri furnitur mengalami masalah ketidakpastian dalam menentukan jumlah persediaan bahan baku kayu yang optimal. Logika fuzzy merupakan salah satu metode yang digunakan untuk menganalisis sistem yang mengandung ketidakpastian. Pada penelitian ini membahas penerapan logika fuzzy dalam menyelesaiakan permasalahan persediaan bahan baku kayu pada industry furnitur dengan pendekatan Fuzzy-Mamdani. Data yang digunakan dalam penelitian ini adalah data pemasukan, penyaluran, dan persediaan bahan baku kayu dari bulan Januari sampai dengan bulan Desember tahun 2018. Perancangan sistem untuk memperoleh output dilakukan dengan tahap-tahap: (a) Pembentukan himpunan fuzzy, (b) Aplikasi fungsi implikasi, (c) Komposisi aturan, (d) Penegasan (defuzzifikasi). Penyelesaian masalah dengan menggunakan metode Fuzzy Tsukamoto dilakukan dengan metode Tsukamoto dengan bantuan software Visual Basic sehingga akan diperoleh hasil yang dinginkan pada variabel output. Dari hasil perhitungan menggunakan metode Fuzzy Tsukamoto, maka dapat dianalisis pembandingan antara persediaan bahan baku kayu realisasi dengan pendekatan Fuzzy Tsukamoto terlihat berbeda dan hasil dari pendekatan Fuzzy Tsukamoto lebih optimal.
\end{abstract}

Kata Kunci: ketidakpastian; persediaan bahan baku kayu; logika Fuzzy; metode Tsukamoto

\section{PENDAHULUAN}

Hampir semua perusahaan yang bergerak di bidang industri pada saat ini dihadapkan pada suatu masalah yaitu adanya tingkat persaingan yang semakin kompetitif [1]. Hal ini mengharuskan perusahaan untuk merencanakan atau menentukan jumlah produksi, agar dapat memenuhi pemesanan 
pasar dengan tepat waktu dan dengan jumlah yang sesuai. Penentuan jumlah produksi dalam perusahaan merupakan suatu hal yang harus diperhatikan sebelum memulai sebuah proses produksi. Perlu dipertimbangkannya berbagai faktor, untuk menghindari risiko meruginya perusahaan [2]. Untuk menyelesaikan masalah tersebut, pihak perusahaan, dalam hal ini manajer, hendaknya dapat membuat suatu keputusan yang tepat untuk memilih berapa banyak jumlah produk yang diproduksi untuk mengoptimalkan keuntungan suatu perusahaan. Salah satu metode yang bisa digunakan adalah dengan fuzzy logic atau logika fuzzy. Logika fuzzy adalah suatu cara yang tepat untuk memetakan suatu ruang input ke dalam suatu ruang output [3] [7]. Teknik ini menggunakan teori matematis himpunan fuzzy. Logika fuzzy berhubungan dengan ketidakpastian yang telah menjadi sifat alamiah manusia. Logika fuzzy dapat bermanfaat karena merupakan sebuah cara yang efektif dan akurat untuk mendeskripsikan persepsi manusia terhadap persoalan pengambilan keputusan. Dalam logika fuzzy variabel yang bersifat kabur tersebut direpresentasikan sebagai sebuah himpunan yang anggotaanggotanya adalah suatu nilai crisp dan derajat keanggotaan di dalam himpunan tersebut [4] [5]. Himpunan tersebut memiliki derajat keanggotaan antara 0 sampai 1, sehingga lebih seimbang dalam mengambil suatu keputusan [6]. Diharapkan dengan adanya penelitian ini akan diperoleh model matematis yang dapat digunakan oleh PT. XYZ dalam melakukan penentuan jumlah persediaan yang optimal.

\section{METODE PENELITIAN}

Pengembangan model matematis untuk menentukan jumlah persediaan optimal mengacu kepada tahapan penelitian menggunakan pendekatan pemodelan sistem sebagai berikut:

Mempelajari perencanaan persediaan di PT. XYZ. Wawancara dan observasi untuk mendapatkan variabel-variabel keputusan penting dalam penentuan jumlah persediaan optimal.

Pengumpulan data berdasarkan variabel-variabel keputusan penting dalam penentuan jumlah persediaan optimal.

Pengembangan model matematis berdasarkan variabel-variabel keputusan penting dalam penentuan jumlah persediaan optimal.

Verifikasi dan validasi model matematis menggunakan data dari PT. XYZ sebagai studi kasus.

\section{HASIL DAN PEMBAHASAN}

Penelitian ini bertujuan untuk memperoleh data yang diperlukan sebagai bahan penunjang dalam rangka penyusunan penelitian ini. Data yang diperoleh diharapkan dapat mendekati masalah, kemudian data tersebut dimodelkan kedalam bentuk model matematika.

Adapun data yang dihimpun dalam penelitian ini adalah bersumber dari PT. XYZ. Data yang dihimpun dalam penelitian ini mencakup data permintaan dari bulan Januari hingga Desember, data jumlah penjualan dari bulan Januari hingga Desember, data produksi dari bulan Januari hingga Desember, dan data jumlah persediaan dari bulan Januari hingga Desember. Data tersebut dapat dilihat pada Tabel 1. sebagai berikut:

Tabel 1. Data Permintaan, Produksi, Penjualan, dan Persediaan

\begin{tabular}{clcccc}
\hline No & Bulan & $\begin{array}{c}\text { Permintaan } \\
(\text { Kubik })\end{array}$ & $\begin{array}{c}\text { Produksi } \\
\text { (Kubik) }\end{array}$ & $\begin{array}{c}\text { Penjualan } \\
(\text { Kubik })\end{array}$ & $\begin{array}{c}\text { Persediaan } \\
\text { (Kubik) }\end{array}$ \\
\hline 1 & Januari & 1735 & 850 & 1850 & 2585 \\
2 & Februari & 2119 & 900 & 2200 & 3019 \\
3 & Maret & 2100 & 1050 & 2350 & 3150 \\
4 & April & 2000 & 750 & 2200 & 2750 \\
5 & Mei & 2400 & 1200 & 2556 & 3600
\end{tabular}




$\begin{array}{llcccc}6 & \text { Juni } & 1990 & 650 & 2180 & 2640 \\ 7 & \text { Juli } & 1842 & 1300 & 2080 & 3142 \\ 8 & \text { Agustus } & 1290 & 950 & 1800 & 2240 \\ 9 & \text { September } & 2400 & 700 & 2500 & 3100 \\ 10 & \text { November } & 2300 & 1000 & 2400 & 3300 \\ 11 & \text { Oktober } & 2100 & 1050 & 2240 & 3150 \\ 12 & \text { Desember } & 2300 & 1000 & 2500 & 3300\end{array}$

\section{Pembentukan Himpunan Fuzzy}

Pada bagian ini Ada 3 variabel fuzzy yang akan dimodelkan, yaitu:

Permintaan; terdiri-atas 2 himpunan fuzzy, yaitu: NAIK dan TURUN (Gambar 1)

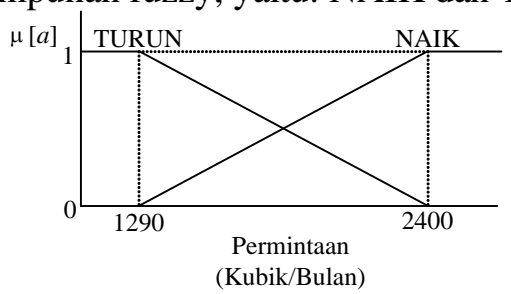

\section{Gambar 1. Fungsi Keanggotaan Variabel Permintaan}

Fungsi kenaggotaan variabel permintaan adalah sebagai berikut:

$$
\begin{gathered}
\mu_{\text {PMITURUN }}[a]= \begin{cases}1, & a \leq 1290 \\
\frac{2400-a}{2400-1290}, & 1290<a<2400 \\
0, & a \geq 2400\end{cases} \\
\mu_{\text {PmtNAIK }}[a]= \begin{cases}0, & a \leq 1290 \\
\frac{a-1290}{2400-1290,}, & 1290<a<2400 \\
1, & a \geq 2400\end{cases}
\end{gathered}
$$

Produksi; terdiri-atas 2 himpunan fuzzy, yaitu: SEDIKIT dan BANYAK (Gambar 2).

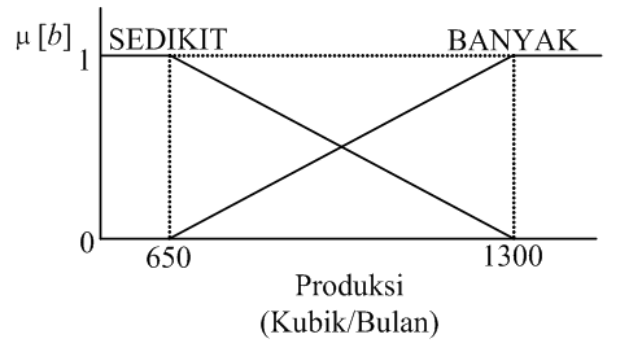

Gambar 2. Fungsi Keanggotaan Variabel Produksi

Fungsi kenaggotaan variabel produksi adalah sebagai berikut: 


$$
\begin{aligned}
& \mu_{\operatorname{Pr} d \text { SEDIKIT }}[b]= \begin{cases}1, & b \leq 650 \\
\frac{1300-b}{1300-650}, & 650<b<1300 \\
0, & b \geq 1300\end{cases} \\
& \mu_{\operatorname{Pr} d B A N Y A K}[b]= \begin{cases}0, & b \leq 650 \\
\frac{b-650}{1300-650}, & 650<b<1300 \\
1, & b \geq 1300\end{cases}
\end{aligned}
$$

Penjualan; terdiri-atas 2 himpunan fuzzy, yaitu: BERKURANG dan BERTAMBAH (Gambar $3)$.

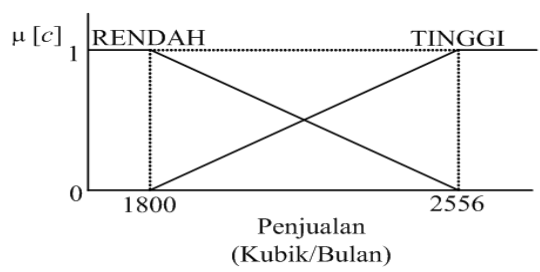

\section{Gambar 3. Fungsi Keanggotaan Variabel Produksi}

Fungsi kenaggotaan variabel permintaan adalah sebagai berikut:

$$
\begin{gathered}
\mu_{\text {PnjRENDAH }}[c]= \begin{cases}1, & c \leq 1800 \\
\frac{2556-c}{2556-1800,}, & 1800<c<2556 \\
0, & c \geq 2556\end{cases} \\
\mu_{\text {PnjTINGGI }}[c]= \begin{cases}0, & c \leq 1800 \\
\frac{c-1800}{2556-1800,}, & 1800<c<2556 \\
1, & c \geq 2556\end{cases}
\end{gathered}
$$

Persediaan; terdiri-atas 2 himpunan fuzzy, yaitu: BERKURANG dan BERTAMBAH (Gambar 4).

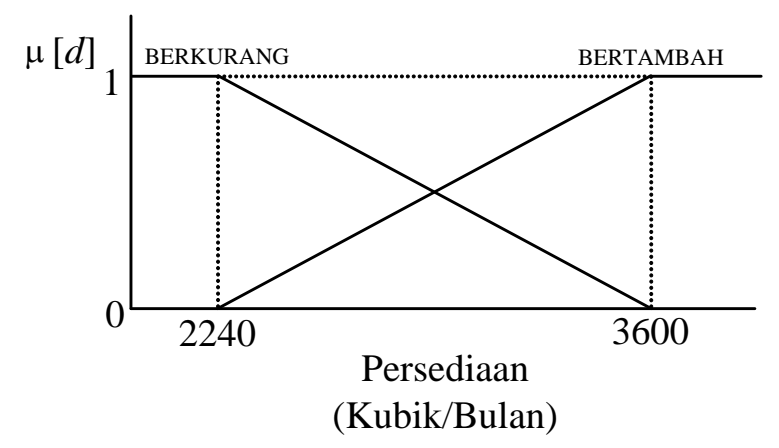

Gambar 4. Fungsi Keanggotaan Variabel Persediaan

Fungsi kenaggotaan variabel persediaan adalah sebagai berikut: 


$$
\begin{aligned}
& \mu_{\operatorname{Pr} B E R K U R A N G}[d]= \begin{cases}1, & d \leq 2240 \\
\frac{3600-d}{3600-2240}, & 2240<d<3600 \\
0, & d \geq 3600\end{cases} \\
& \mu_{\operatorname{Pr} \text { BERTAMBAH }}[d]= \begin{cases}0, & d \leq 2240 \\
\frac{d-2240}{3600-2240}, & 2240<d<3600 \\
1, & d \geq 3600\end{cases}
\end{aligned}
$$

\section{Komposisi Aturan}

Komposisi aturan pada penelitian ini, disusun berdasarkan operator Zadeh. Rincian aturan yang telah dibuat adalah sebagai berikut [7] [9]:

[R1] IF Permintaan TURUN And Produksi SEDIKIT And Penjualan RENDAH THEN Persediaan BERKURANG;

[R2] IF Permintaan TURUN And Produksi SEDIKIT And Penjualan RENDAH THEN Persediaan BERTAMBAH;

[R3] IF Permintaan TURUN And Produksi SEDIKIT And Penjualan TINGGI THEN Persediaan BERKURANG;

[R4] IF Permintaan TURUN And Produksi SEDIKIT And Penjualan TINGGI THEN Persediaan BERTAMBAH;

[R5] IF Permintaan TURUN And Produksi BANYAK And Penjualan RENDAH THEN Persediaan BERKURANG;

[R6] IF Permintaan TURUN And Produksi BANYAK And Penjualan RENDAH THEN Persediaan BERTAMBAH;

[R7] IF Permintaan TURUN And Persediaan BANYAK And Penjualan TINGGI THEN Produksi BERKURANG;

[R8] IF Permintaan TURUN And Produksi BANYAK And Penjualan TINGGI THEN Persediaan BERTAMBAH;

[R9] IF Permintaan NAIK And Persediaan SEDIKIT And Penjualan RENDAH THEN Produksi BERKURANG;

[R10] IF Permintaan NAIK And Produksi SEDIKIT And Penjualan RENDAH THEN Persediaan BERTAMBAH;

[R11] IF Permintaan NAIK And Produksi SEDIKIT And Penjualan TINGGI THEN Persediaan BERKURANG;

[R12] IF Permintaan NAIK And Produksi SEDIKIT And Penjualan TINGGI THEN Persediaan BERTAMBAH;

[R13] IF Permintaan NAIK And Persediaan BANYAK And Penjualan RENDAH THEN Produksi BERKURANG;

[R14] IF Permintaan NAIK And Produksi BANYAK And Penjualan RENDAH THEN Persediaan BERTAMBAH;

[R15] IF Permintaan NAIK And Produksi BANYAK And Penjualan TINGGI THEN Persediaan BERKURANG;

[R16] IF Permintaan NAIK And Produksi BANYAK And Penjualan TINGGI THEN Persediaan BERTAMBAH;

\section{Analisis Data}

Diketahui permintaan pada periode ini adalah 2000 kubik, produksi pada periode ini adalah 750 kubik, penjulan pada periode ini adalah 2000 kubik. Berdasarkan model dan aturan yang telah dibuat akan ditentukan jumlah persediaan pada periode ini. Berikut ini adalah analisis data berdasarkan model dan aturan yang telah dibuat atau telah dimodelkan pada periode sebelumnya.

Penentuan nilai keanggotaan untuk masing-masing variabel adalah sebagai berikut:

Nilai Keanggotaan Variabel Permintaan 
Diketahui permintaannya adalah 2000 kubik dengan menggunakan persamaan 1 dan persamaan 2, maka diperoleh hasil perhitungan sebagai berikut ini:

$\begin{array}{lll}\mu_{\text {PmtTURUN }}[2000] & =(2400-2000) /(2400-1290) & =0,36 \\ \mu_{\text {PmtNAIK }}[2000] & =(2000-1290) /(2400-1290) & =0,64\end{array}$

Sehingga, Jika digambarkan dalam bentuk grafik adalah sebagai berikut:

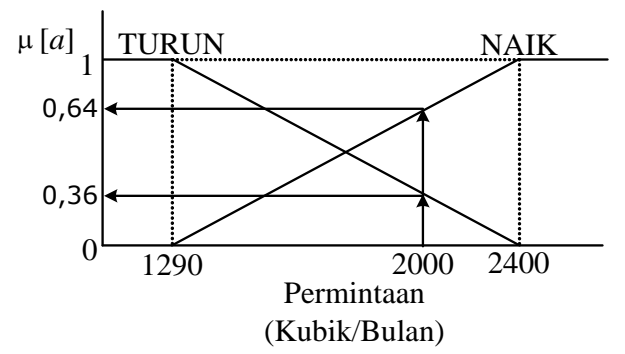

\section{Gambar 5. Nilai Keanggotaan Variabel Permintaan}

Nilai Keanggotaan Variabel Produksi

Diketahui produksinya adalah 750 kubik dengan menggunakan persamaan 3 dan persemaan 4, maka diperoleh hasil perhitungan sebagai berikut ini:
$\mu_{\text {PrdSEDIKIT }[750]}$
$=(1300-650) /(1300-750)$
$=0,85$
$\mu_{\text {PrdBANYAK }}[750]$
$=(750-650) /(1300-750)$
$=0,15$

Sehingga, Jika digambarkan dalam bentuk grafik adalah sebagai berikut:

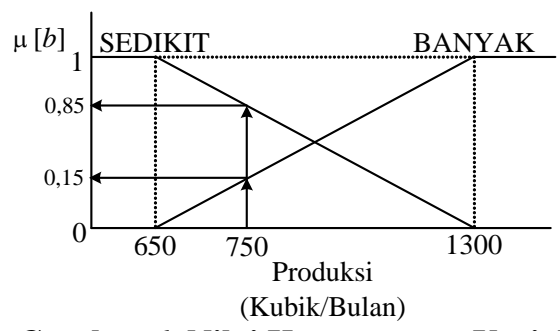

Gambar 6. Nilai Keanggotaan Variabel Produksi

Nilai Keanggotaan Variabel Penjualan

Diketahui penjualannya adalah 2000 kubik dengan menggunakan persamaan 5 dan persamaan 6 , maka diperoleh hasil perhitungan sebagai berikut ini:

$$
\begin{array}{lll}
\mu_{\text {PnjRENDAH }}[2000] & =(2556-2000) /(2556-1800) & =0,74 \\
\mu_{\text {PnjTINGGI }}[2000] & =(2000-1800) /(2556-1800) & =0,26
\end{array}
$$

Sehingga, Jika digambarkan dalam bentuk grafik adalah sebagai berikut:

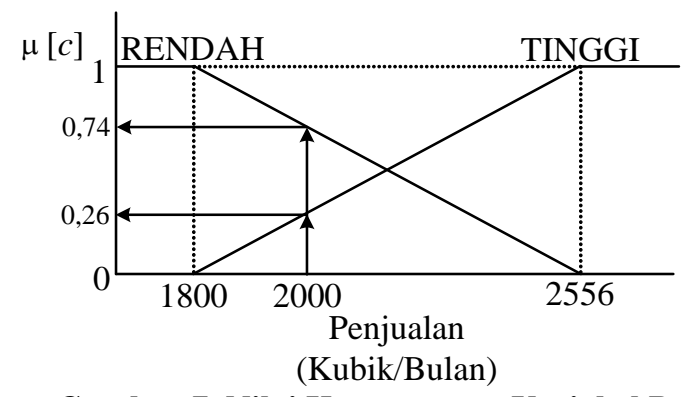

Gambar 7. Nilai Keanggotaan Variabel Penjualan

Pengolahan data yang selanjutnya adalah mencari nilai $d$ (jumlah persediaan) untuk setiap aturan dengan menggunakan fungsi MIN pada aplikasi fungsi implikasinya. Rincian perhitungan untuk masing-masing aturan yang digunakan adalah sebagai berikut: 


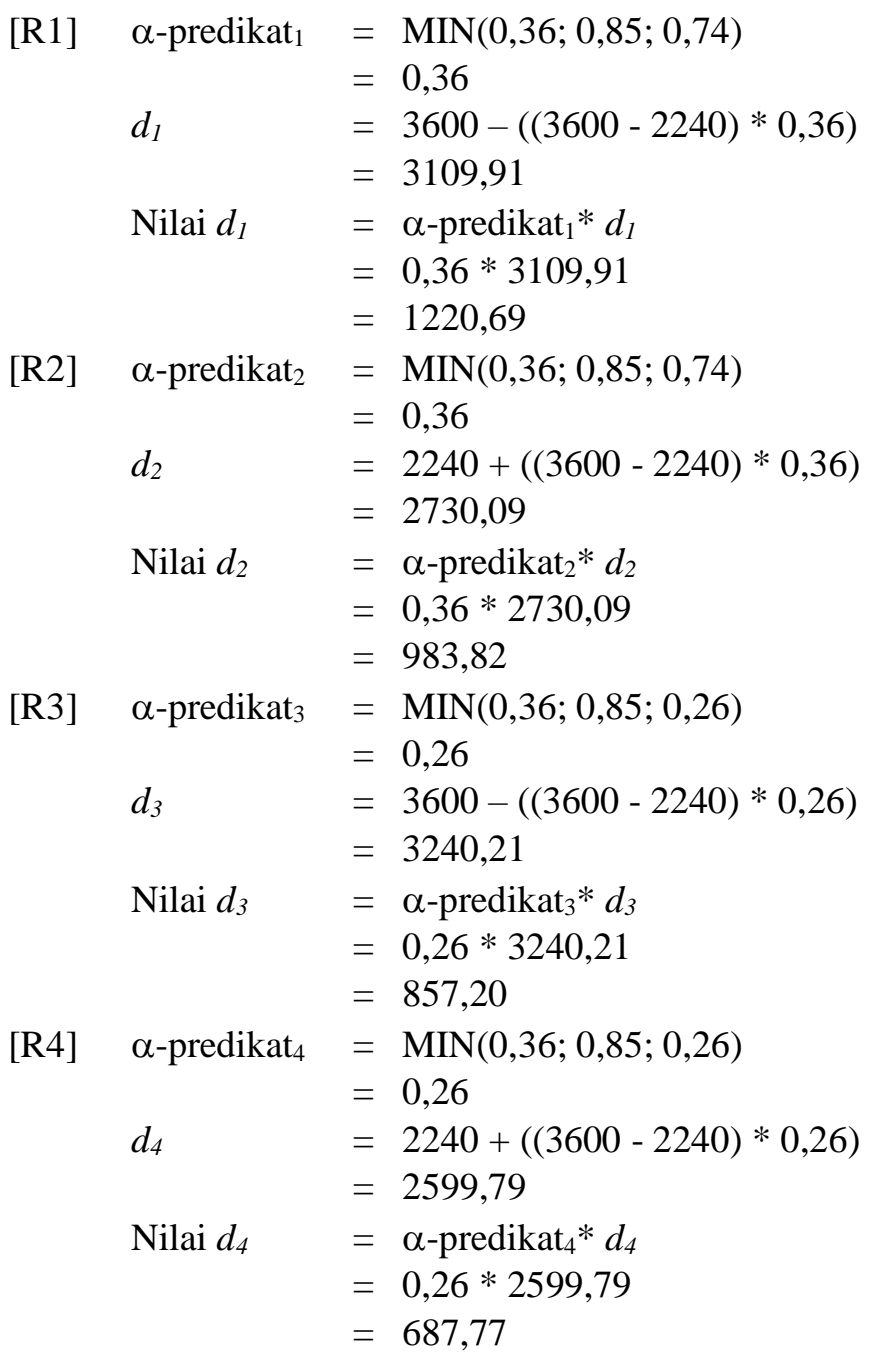

Tabel 2. Prediksi Jumlah Persediaan

\begin{tabular}{ccccccc}
\hline $\begin{array}{c}\text { NILAI } \\
\text { ATURAN }\end{array}$ & $\begin{array}{c}\text { PERMINTAA } \\
\text { N }\end{array}$ & $\begin{array}{c}\text { PRODUK } \\
\text { SI }\end{array}$ & $\begin{array}{c}\text { PENJUALA } \\
\text { N }\end{array}$ & $\begin{array}{c}\text { MI } \\
\text { N }\end{array}$ & $\begin{array}{c}\text { PERSEDIAAN } \\
(\mathbf{Z})\end{array}$ & $\begin{array}{c}\text { Prediksi } \\
(\mathbf{Z})\end{array}$ \\
\hline R1 & 0.36 & 0.85 & 0.74 & $\mathbf{0 . 3 6}$ & $\mathbf{3 1 0 9 . 9 1}$ & $\mathbf{1 1 2 0 . 6 9}$ \\
R2 & 0.36 & 0.85 & 0.74 & $\mathbf{0 . 3 6}$ & $\mathbf{2 7 3 0 . 0 9}$ & $\mathbf{9 8 3 . 8 2}$ \\
R3 & 0.36 & 0.85 & 0.26 & $\mathbf{0 . 2 6}$ & $\mathbf{3 2 4 0 . 2 1}$ & $\mathbf{8 5 7 . 2 0}$ \\
R4 & 0.36 & 0.85 & 0.26 & $\mathbf{0 . 2 6}$ & $\mathbf{2 5 9 9 . 7 9}$ & $\mathbf{6 8 7 . 7 7}$ \\
R5 & 0.36 & 0.15 & 0.74 & $\mathbf{0 . 1 5}$ & $\mathbf{3 3 9 0 . 7 7}$ & $\mathbf{5 2 1 . 6 6}$ \\
R6 & 0.36 & 0.15 & 0.74 & $\mathbf{0 . 1 5}$ & $\mathbf{2 4 4 9 . 2 3}$ & $\mathbf{3 7 6 . 8 0}$ \\
R7 & 0.36 & 0.15 & 0.26 & $\mathbf{0 . 1 5}$ & $\mathbf{3 3 9 0 . 7 7}$ & $\mathbf{5 2 1 . 6 6}$ \\
R8 & 0.36 & 0.15 & 0.26 & $\mathbf{0 . 1 5}$ & $\mathbf{2 4 4 9 . 2 3}$ & $\mathbf{3 7 6 . 8 0}$ \\
R9 & 0.64 & 0.85 & 0.74 & $\mathbf{0 . 6 4}$ & $\mathbf{2 7 3 0 . 0 9}$ & $\mathbf{1 7 4 6 . 2 7}$ \\
R10 & 0.64 & 0.85 & 0.74 & $\mathbf{0 . 6 4}$ & $\mathbf{3 1 0 9 . 9 1}$ & $\mathbf{1 9 8 9 . 2 2}$
\end{tabular}




\begin{tabular}{|c|c|c|c|c|c|c|}
\hline $\begin{array}{c}\text { NILAI } \\
\text { ATURAN }\end{array}$ & $\begin{array}{c}\text { PERMINTAA } \\
\mathbf{N}\end{array}$ & $\begin{array}{l}\text { PRODUK } \\
\text { SI }\end{array}$ & $\begin{array}{c}\text { PENJUALA } \\
\mathbf{N}\end{array}$ & $\begin{array}{c}\text { MI } \\
\mathbf{N}\end{array}$ & $\begin{array}{c}\text { PERSEDIAAN } \\
(\mathrm{Z})\end{array}$ & $\begin{array}{l}\text { Prediksi } \\
(\mathrm{Z})\end{array}$ \\
\hline R11 & 0.64 & 0.85 & 0.26 & 0.26 & 3240.21 & 857.20 \\
\hline $\mathrm{R} 12$ & 0.64 & 0.85 & 0.26 & 0.26 & 2599.79 & 687.77 \\
\hline $\mathrm{R} 13$ & 0.64 & 0.15 & 0.74 & 0.15 & 3390.77 & 521.66 \\
\hline R14 & 0.64 & 0.15 & 0.74 & 0.15 & 2449.23 & 376.80 \\
\hline R15 & 0.64 & 0.15 & 0.26 & 0.15 & 3390.77 & 521.66 \\
\hline \multirow[t]{3}{*}{$\mathrm{R} 16$} & 0.64 & 0.15 & 0.26 & 0.15 & 2449.23 & 376.80 \\
\hline & & & & 4.29 & & 12523.79 \\
\hline & & & & & $\begin{array}{l}\text { Nilai Produksi } \\
(\mathrm{Z})\end{array}$ & 2920.00 \\
\hline \multirow{5}{*}{$d$} & \multicolumn{4}{|c|}{$1120,69+983,82+\cdots+376,80$} & & \\
\hline & \multicolumn{2}{|c|}{$0,36+0,36+\cdots+0,15$} & & & & \\
\hline & \multicolumn{2}{|l|}{12523,79} & & & & \\
\hline & \multicolumn{2}{|l|}{4,29} & & & & \\
\hline & 2920,00 & & & & & \\
\hline
\end{tabular}

Penentuan nilai $d$ atau proses defuzzifikasi menggunakan persamaan 7 dan persamaan 8 sehingga diperoleh jumlah persediaan yang harus disediakan berdasarkan model yang telah dibangun adalah sebanyak 2920 kubik.

\section{Pembentukan Himpunan Fuzzy}

Berdasarkan hasil penelitian yang telah dilakukan, serta uraian-uraian yang telah dikemukakan, terdapat empat variabel yang digunakan dalam penelitian ini adalah variabel permintaan, produksi, penjualan dan persediaan. Empat variabel ini digunakan karena berdasarkan kondisi yang ada di perusahaan. Perusahaan menyatakan bahwa variabel-variabel yang saling berpengaruh adalah permintaan, penerimaan dan persediaan [7] [8] [9].

Variabel permintaan terdiri dari dua himpunan, yaitu himpunan turun dan himpunan naik. Untuk himpunan turun mempunyai nilai minimal sebesar 1290 Kubik, sedangkan untuk himpunan naik mempunyai nilai maksimal sebesar 2400 Kubik. Penentuan nilai-nilai untuk masing-masing himpunan dalam penelitian ini didasarkan pada data yang telah dikumpulkan dalam penelitian ini. Selain itu, penentuan ini merupakan penentuan himpunan yang paling saderhana, sehingga diperoleh hasil seperti pada bagian ini.

Variabel produksi terdiri dari dua himpunan, yaitu himpunan sedikit dan himpunan banyak. Untuk himpunan sedikit mempunyai nilai minimal sebesar 650 Kubik, sedangkan untuk himpunan banyak mempunyai nilai maksimal sebesar 1300 Kubik. Penentuan nilai-nilai untuk masing-masing himpunan dalam penelitian ini didasarkan pada data yang telah dikumpulkan dalam penelitian ini. Selain itu, penentuan ini merupakan penentuan himpunan yang paling sederhana, sehingga diperoleh hasil seperti pada bagian ini.

Variabel penjualan terdiri dari dua himpunan, yaitu himpunan rendah dan himpunan tinggi. Untuk himpunan berkurang mempunyai nilai minimal sebesar 1800 Kubik, sedangkan untuk himpunan bertambah mempunyai nilai maksimal sebesar 2556 Kubik. Penentuan nilai-nilai untuk masing-masing himpunan dalam penelitian ini didasarkan pada data yang telah dikumpulkan dalam penelitian ini. Selain itu, penentuan ini merupakan penentuan himpunan yang paling saderhana, sehingga diperoleh hasil seperti pada bagian ini.

Variabel persediaan terdiri dari dua himpunan, yaitu himpunan berkurang dan himpunan bertambah. Untuk himpunan berkurang mempunyai nilai minimal sebesar 2240 Kubik, sedangkan 
untuk himpunan bertambah mempunyai nilai maksimal sebesar 3600 Kubik. Penentuan nilai-nilai untuk masing-masing himpunan dalam penelitian ini didasarkan pada data yang telah dikumpulkan dalam penelitian ini. Selain itu, penentuan ini merupakan penentuan himpunan yang paling saderhana, sehingga diperoleh hasil seperti pada bagian ini.

\section{Penentuan Aturan}

Dalam metode fuzzy diperlukan penentuan aturan yang nantinya akan digunakan untuk menentukan variabel yang akan ditentukan [7] [8] [9] [10]. Hal ini, dilakukan sesuai dengan langkah dari metode yang digunakan dalam penelitian ini. Dalam penelitian ini aturan yang digunakan terdiri dari enam belas aturan. Diantaranya adalah "IF Permintaan TURUN And Produksi SEDIKIT And Penjualan RENDAH THEN Persediaan BERKURANG;" aturan ini mempunyai kesimpulan fungsi persediaan berkurang. Selanjutnya "IF Permintaan TURUN And Produksi SEDIKIT And Penjualan RENDAH THEN Persediaan BERTAMBAH;" aturan ini mempunyai kesimpulan fungsi persediaan bertambah. Selanjutnya "IF Permintaan TURUN And Produksi SEDIKIT And Penjualan TINGGI THEN Persediaan BERKURANG;" aturan ini mempunyai kesimpulan fungsi persediaan berkurang. Selanjutnya "IF Permintaan TURUN And Produksi SEDIKIT And Penjualan TINGGI THEN Persediaan BERTAMBAH;" aturan ini mempunyai kesimpulan fungsi persediaan bertambah. Selanjutnya "IF Permintaan TURUN And Produksi BANYAK And Penjualan RENDAH THEN Persediaan BERKURANG;" aturan ini mempunyai kesimpulan fungsi persediaan berkurang. Selanjutnya "IF Permintaan TURUN And Produksi BANYAK And Penjualan RENDAH THEN Persediaan BERTAMBAH;" aturan ini mempunyai kesimpulan fungsi persediaan bertambah. Selanjutnya "IF Permintaan TURUN And Persediaan BANYAK And Penjualan TINGGI THEN Produksi BERKURANG;" aturan ini mempunyai kesimpulan fungsi persediaan berkurang. Selanjutnya "IF Permintaan TURUN And Produksi BANYAK And Penjualan TINGGI THEN Persediaan BERTAMBAH;" aturan ini mempunyai kesimpulan fungsi persediaan bertambah. Selanjutnya "IF Permintaan NAIK And Persediaan SEDIKIT And Penjualan RENDAH THEN Produksi BERKURANG;" aturan ini mempunyai kesimpulan fungsi persediaan berkurang. Selanjutnya "IF Permintaan NAIK And Produksi SEDIKIT And Penjualan RENDAH THEN Persediaan BERTAMBAH;" aturan ini mempunyai kesimpulan fungsi persediaan bertambah. Selanjutnya "IF Permintaan NAIK And Produksi SEDIKIT And Penjualan TINGGI THEN Persediaan BERKURANG;" aturan ini mempunyai kesimpulan fungsi persediaan berkurang. Selanutnya "IF Permintaan NAIK And Produksi SEDIKIT And Penjualan TINGGI THEN Persediaan BERTAMBAH;" aturan ini mempunyai kesimpulan fungsi persediaan bertambah. Selanjutnya "IF Permintaan NAIK And Persediaan BANYAK And Penjualan RENDAH THEN Produksi BERKURANG;" aturan ini mempunyai kesimpulan fungsi persediaan berkurang. Selanjutnya "IF Permintaan NAIK And Produksi BANYAK And Penjualan RENDAH THEN Persediaan BERTAMBAH;" aturan ini mempunyai kesimpulan fungsi persediaan bertambah. Selanjutnya "IF Permintaan NAIK And Produksi BANYAK And Penjualan TINGGI THEN Persediaan BERKURANG;" aturan ini mempunyai kesimpulan fungsi persediaan berkurang. Selanjutnya "IF Permintaan NAIK And Produksi BANYAK And Penjualan TINGGI THEN Persediaan BERTAMBAH;" aturan ini mempunyai kesimpulan fungsi persediaan bertambah.

\section{Analisis Data}

Dalam metode fuzzy diperlukan penentuan aturan yang nantinya akan digunakan untuk menentukan variabel yang akan ditentukan [7] [9]. Hal ini, dilakukan sesuai dengan langkah dari metode yang digunakan dalam penelitian ini. Diketahui jumlah permintaan pada periode ini adalah 2000 kubik, jumlah produksi pada periode ini adalah 750 kubik, jumlah penjulan pada periode ini adalah 2000 kubik, maka diperoleh hasil untuk jumlah persediaan pada periode ini sebesar 2090 kubik. Berdasarkan model dan aturan yang telah dibuat akan ditentukan jumlah persediaan pada periode ini. Berikut ini adalah analisis data berdasarkan model dan aturan yang telah dibuat atau telah dimodelkan pada periode sebelumnya. Diketahui permintaannya adalah 2000 Kubik dengan menggunakan persamaan 1 dan persamaan 2, maka diperoleh hasil perhitungan sebagai permintaan turun mempunyai nilai keanggotaan sebesar 0,36 dan permintaan naik mempunyai nilai keanggotaan sebesar 0,64. Diketahui produksinya adalah 750 Kubik dengan menggunakan persamaan 3 dan persemaan 4, maka diperoleh hasil perhitungan untuk produksi sedikit mempunyai nilai keanggotaan 
sebesar 0,85. Sedangkan untuk produksi banyak mempunyai nilai keanggotaan sebesar 0,15. Diketahui penjualannya adalah 2000 Kubik dengan menggunakan persamaan 5 dan persemaan 6 , maka diperoleh hasil perhitungan untuk penjualan rendah mempunyai nilai keanggotaan sebesar 0,74. Sedangkan untuk penjualan tinggi mempunyai nilai keanggotaan sebesar 0,26. Nilai dari masingmasing fungsi keanggotaan ini nantinya akan dimasukkan kedalam aturan-aturan yang telah diracang sebelumnyan untuk mengetahui besarnya nilai persediaan yang optimal. Sehingga dengan menggunakan persamaan 7 dan persamaan 8 sehingga diperoleh jumlah persediaan yang harus disediakan berdasarkan model yang telah dibangun adalah sebanyak 2920 kubik.

\section{KESIMPULAN}

Berdasarkan kasus yang telah diteliti, diperoleh kesimpulan sebagai berikut:

Variabel-variabel penting dalam perancangan model matematis adalah variabel permintaan, variabel produksi, varibel penjualan dan variabel persediaan.

Berdasarkan model matematis yang telah dirancang dengan memasukkan variabel input, yaitu jumlah permintaan pada periode ini adalah 2000 kubik, jumlah produksi pada periode ini adalah 750 kubik, jumlah penjulan pada periode ini adalah 2000 kubik, maka diperoleh hasil untuk jumlah persediaan pada periode ini sebesar 2090 kubik.

\section{DAFTAR PUSTAKA}

Cox, Earl., 1994, The Fuzzy System Handbook, Massachusetts: Academic Press-Inc

Daihani, D.U., 2001, Komputerisasi Pengambilan Keputusan, Jakarta: PT Elex Media Komputindo.

Hasan, M.I., 2004, Pokok-Pokok Materi Teori Pengambilan Keputusan, Bogor Selatan: Ghalia Indonesia.

Jang, J.R., Sun, C.T., dan Mizutami, E., 1997, Neuro Fuzzy and Soft Computing. London: PrenticeHall.

Klir, J.R., Bo Yuan, 1999. Fuzzy sets and Fuzzy Logic Theory and Aplications, New Jersey: Prentice Hall.

Kosko, Bart., 1997, Fuzzy Engineering, New Jersey: Prentice-Hall, Inc.

Kusrini., 2007, Konsep dan Aplikasi Sistem Pendukung Keputusan, Yogyakarta: Andi.

Kusumadewi, S., 2003, Artificial Intelligence (Teknik dan Aplikasinya), Yogyakarta: Graha Ilmu.

Kusumadewi, S dan Purnomo, H., 2004, Aplikasi Logika Fuzzy Untuk Pendukung Keputusan, Yogyakarta: Graha Ilmu.

Nasution, A. H., dan Prasetyawan, Y., 2008, Perencanaan dan Pengendalian Produksi. Yogyakarta: Graha Ilmu. 